\title{
Effect of Partial Substitution of Wheat Flour by Processed (Germinated, Toasted, Cooked) Chickpea on Bread Quality
}

\author{
Impact of Processed Chickpea Flour on Bread Quality
}

\author{
Meriem Ouazib ${ }^{1,2}$, Angela Dura ${ }^{1}$, Farid Zaidi ${ }^{2}$, Cristina M. Rosell ${ }^{1 *}$ \\ Institute of Agrochemistry and Food Technology (IATA-CSIC), AvenidaAugustinEscardino, 7, Paterna 46980, \\ Valencia, Spain- Department of Food Science, Faculty of Nature and Life Sciences, Abderrahmane Mira University, \\ Route Targa-Ouzemour, Bejaia 06000, Algeria \\ 1,2meriemouazib@hotmail.fr; ${ }^{1}$ andudemi@iata.csic.es; 2idiazdiraf@yahoo.fr; ${ }^{1 *}$ crosell@iata.csic.es
}

\begin{abstract}
The effect of partial substitution of wheat flour with either raw and processed chickpea (germinated, toasted and cooked) flour at different levels (10 and $20 \%$ ) on pasting properties of composite flours and on physical and nutritional parameters of the composite breads were studied. Composite flours of wheat and processed chickpea showed different pasting properties, decreasing the viscosity in all kinds of flour and levels, being more accentuated with the cooked flour. The least affected flour was the toasted that showed similar pasting profile than raw flour. Breads with $10 \%$ wheat flour replacement showed minor changes in their quality, but $20 \%$ replacement resulted in great detriment of the quality. Crumb hardness was greatly improved when $20 \%$ raw or toasted flour was incorporated. Overall, germinated chickpea flours were the most appropriate flour for wheat replacement pertaining bread specific volume, crumb hardness and nutritional composition (higher protein content).
\end{abstract}

Keywords

Legumes; Chickpea Flour; Bread; Germination; Cooking; Toasting; Quality

\section{Introduction}

Chickpea (Cicerarietinum L.) is one of the top five important legumes on the basis of whole grain production [1], and the second most important cool season pulse crop in the world. It is grown in at least 33 countries including Central and West Asia, South Europe, Ethiopia, North and South America, Australia and North Africa [2]. In Algeria, chickpeas and broad beans are the most cultivated dry legumes [3], widely consumed and are almost present in all traditional dishes. Various traditional oriental foods are prepared using chickpea floor slurry, both at household and industrial levels [4]. Regarding nutritional value, chickpea seed has high protein digestibility, contains high levels of complex carbohydrates and it is rich in vitamins and minerals [5]. Chickpea seed is processed and cooked in a variety of forms depending upon traditional practices and taste preferences. Different domestic processing methods (decortications, soaking, sprouting, fermentation, boiling, roasting, parching, frying, steaming) remove anti-nutritional factors and increase the protein digestibility of chickpea seed [6]. Although till recently consumers have neglected legumes, currently they are becoming increasingly health mindful. Bread fortification is one of the most successful strategies to mitigate nutrition deficiencies in developing countries [7]. Legumes combined with cereals constitute one of the worldwide staple commodities. Combination of cereal and legumes is effective and interesting; both have limiting essential amino acids that human body is not able to synthesize and it is needed to get them from food intake. Legumes are limited in methionine essential amino acid and rich in lysine, while cereals are lysine limiting amino acid [8]. In fact, several studies have focused on the influence of the addition of legume flours on the functional properties of doughs and final baked products quality [9-11]. In addition, some attentions have been paid to the effect of different types of pulses added to wheat flour to obtain baked goods and processed bread [12-14]. Nevertheless, there is no information about the effect of diverse processed chickpea flours on wheat flour replacement for breadmaking. Since chickpea is considered as an ideal 
complement to cereals in a healthy diet, it is taken into concern the possibility of replacing cereal-based products by the substitution of raw or processed chickpea flour to reduce the dependence of some countries on wheat importations. Therefore, the present work was undertaken to better understand the effects of substitution of wheat flour with raw and treated (germinated, toasted and cooked) chickpea flour at two levels 10 and $20 \%$ on the pasting properties of the flour blend, as well as to study the effect of substituting wheat flour by 10 and $20 \%$ of chickpea flour on physical, chemical and sensorial parameters of final bread.

\section{Material and Methods}

\section{Materials}

Chickpea was grown in winter 2013 and harvested in June 2013, in the region of Merj-Ouamane, commune of Amizour, wilaya of Bejaia; Algeria. Wheat flour was supplied by Harinera La Meta (Lleida,Spain), dry baker's yeast (Lesaffre, France) and salt were purchased from the local market.

\section{Preparation of Chickpea's Flour}

Four types of chickpea flour were compared: raw chickpea, germinated chickpea, cooked and toasted chickpea. Germinated chickpea flour were obtained by soaking chickpea seeds in tap water $(1: 10 \mathrm{w} / \mathrm{v})$ for $12 \mathrm{~h}$ at room temperature $\left(2{ }^{\circ} \mathrm{C} \pm 2\right)$ and kept in the dark, then seeds were germinated between two sheets of wet filter papers for $48 \mathrm{~h}$ at room temperature in the dark $\left(22{ }^{\circ} \mathrm{C} \pm 2\right)$. Germinated seeds were dried overnight in stove at $60{ }^{\circ} \mathrm{C}$ before subjected to milling.

Cooked chickpea flour were obtained by soaking as described before and then samples were cooked for $15 \mathrm{~min}$ until reaching soft texture when pressing between the fingers. Cooked seeds were rinsed with tap water, drained and dried overnight at $60^{\circ} \mathrm{C}$ before milling.

Toasted chickpea flour was obtained by toasting cleaned chickpea seeds in stove (Bergstr.14D-78532, Tuttlingen) at $180^{\circ} \mathrm{C}$ for $20 \mathrm{~min}$.

All the processed chickpea seeds and the raw chickpea seeds were ground into flour with a mortar and a pestle and then with a coffee grinder. The obtained powder was passed through a $0.5 \mathrm{~mm}$ screen to remove particle clumps and then flours were stored in air-tight plastic containers and held at $4^{\circ} \mathrm{C}$ until further analysis.

\section{Flour Composition}

The contents of moisture, ash, fat and crude protein $(\% \mathrm{~N} \times 6.25)$ of the flour were determined according to AOAC official methods [15]. The percentage of carbohydrates was estimated by difference $[100-(\%$ protein $+\%$ fat $+\%$ ash $+\%$ water)].

\section{Pasting Properties of Flour Mixtures}

Flour blends of chickpea flours and wheat flour were prepared at two different ratios 10:90 and 20:80 (g:g). Pasting properties of flour blends were determined using a rapid visco analyzer (RVA) (Newport Scientific Pty Ltd., Australia) by following the AACCI method [16], with some minor modifications. Sample ( $3 \mathrm{~g}$ based on $14 \mathrm{~g}$ of moisture per $100 \mathrm{~g}$ of flours blend) was added to $25 \mathrm{~mL}$ of water. RVA settings during assessment were heating from 50 to $95{ }^{\circ} \mathrm{C}$ in $282 \mathrm{~s}$, holding at $95^{\circ} \mathrm{C}$ for $150 \mathrm{~s}$ and then cooling to $50{ }^{\circ} \mathrm{C}$. Each cycle was initiated by a $10 \mathrm{~s}, 960$ rpm paddle speed for mixing followed by a $160 \mathrm{rpm}$ paddle speed for the rest of the assay. Viscosity was recorded during a heating-cooling cycle using Thermocline software for Windows (Perten, Stockholm, Sweden). Peak viscosity (maximum viscosity during heating), breakdown (decay of viscosity during heating), final viscosity (viscosity at the end of cooling) and setback (difference between final viscosity and peak viscosity) were evaluated. Samples were run in duplicate.

\section{Breadmaking Process}

Breads with different levels of chickpea flour were formulated: bread at $100 \%$ wheat flour, bread at $20 \%$ chickpea 
flour (raw and treated), and bread at 10\% chickpea flour (raw and treated). The bread dough formula consisted of $300 \mathrm{~g}$ flour (wheat or blends), $4.5 \mathrm{~g}$ salt, $2.1 \mathrm{~g}$ dry yeast (Saf-instant, Lesaffre Group, France) and water. Dry ingredients were mixed in a Farinograh (Brabender, Duisburg, Germany) for $30 \mathrm{~s}$ at $30{ }^{\circ} \mathrm{C}$ and then water was added and mixed again for $7 \mathrm{~min}$ at $30^{\circ} \mathrm{C}$. Water content was adjusted to keep constant the dough consistency (172.5 ml for wheat bread, raw 10 and $20 \%, 180.5 \mathrm{ml}$ for germinated $10 \%, 185.5 \mathrm{ml}$ for germinated $20 \%, 181.5 \mathrm{ml}$ for toasted $10 \%, 189.5 \mathrm{ml}$ for toasted $20 \%, 187.5 \mathrm{ml}$ for cooked $10 \%$, and $197.5 \mathrm{ml}$ for cooked $20 \%$ ). Dough was divided into 9 hand-rounded pieces $(50 \mathrm{~g})$ that were mechanically molded. Proofing was carried out in a fermentation cabinet (Salva Industrial S.A., Lezo, Guipuzcoa, Spain) for $55 \mathrm{~min}$ at $30{ }^{\circ} \mathrm{C}$ and baked into an electric oven (Salva Industrial S.A., Lezo, Guipuzcoa, Spain) for $25 \mathrm{~min}$ at $180^{\circ} \mathrm{C}$. Loaves were cooled down for $30 \mathrm{~min}$ at room temperature and then packed into polyethylene pouches till further analysis. Two sets of breads were made for each flour blends.

Bread samples were coded for wheat $(W)$, raw chickpea $(R)$, germinated chickpea $(G)$, toasted chickpea $(T)$ and cooked chickpea (C), followed with $10 \%$ or $20 \%$ to indicate the amount of chickpea flour used for making the blends.

\section{Bread Quality Parameters}

\section{1) Instrumental Parameters}

Technological parameters of bread quality included: volume (rapeseed displacement) [16], specific volume (by dividing volume by weight), moisture content [16], crumb color and crumb texture profile analysis (TPA). The color of the bread crumbs was measured at three different locations. A colorimeter (Chroma Meter CR-400/410, Konica Minolta, Japan) was used to measure the crumb colour parameters $\left(L^{*}, a^{*}, b^{*}\right)$. The results were expressed in accordance with the CIELAB system (D65 illuminant and $10^{\circ}$ viewing angle). The measurements were made with a $30 \mathrm{~mm}$ diameter diaphragm inset with optical glass. The parameters measured were $L^{*}\left(L^{*}=0\right.$ [black], $L^{*}=100$ [white] indicates lightness, $a^{*}$ indicates hue on a green $\left(-a^{*}\right)$ to red $\left(+a^{*}\right)$ axis, and $b^{*}$ indicates hue on a blue $\left(-b^{*}\right)$ to yellow $\left(+b^{*}\right)$ axis. Chroma $\left(C^{*}\right)$ and hue angle $\left(h^{\circ}\right)$ were calculated using the following equation: $\left(a^{* 2}+b^{* 2}\right)^{1 / 2}$ and the arctangent of $b^{*} / a^{*}$, respectively. Data from three slices per bread were averaged for each batch.

Crumb texture analysis was carried out on uniform slices of $10 \mathrm{~mm}$ thickness. Four slices from the center of each loaf were taken for evaluation. Texture profile analysis (TPA) was performed using a universal testing machine TA.XTplus (Stable Micro Systems Ltd., Godalming, UK) equipped with a stainless steel cylinder probe ( $\mathrm{P} / 25,25 \mathrm{~mm}$ diameter). A double compression test up to 50\% penetration of its original height at a crosshead speed of $1 \mathrm{~mm} / \mathrm{s}$ and a $30 \mathrm{~s}$ gap between compressions was carried out. Hardness, cohesiveness, springiness, chewiness and resilience were calculated from the TPA recorded plot using the software "Texture Expert".

\section{2) Chemical Composition of Breads}

The chemical composition of bread samples was determined according to AOAC official methods [15]. The percentage of carbohydrates was estimated by difference [100 $-(\%$ protein $+\%$ fat $+\%$ ash $+\%$ water $)]$.

\section{3) Sensory Evaluation}

A descriptive sensory analysis was preliminary performed for evaluating the sensory characteristics, and then a quantitative descriptive sensory analysis. Bread slices, including crust and crumb, were presented ( $1 \mathrm{~cm}$ thick) on plastic dishes coded and served in randomized order under normal lightening conditions and at room temperature. Twelve trained panelists that had participated in descriptive analysis and scale rating of a wide range of bread products for more than 10 years carried out this evaluation. Preliminary training test was performed, in which they were sat in a round table and after evaluating the sample, an open discussion was initiated for defining and describing the best descriptors for characterizing the product. Evaluation included perception at first glance of the bread slice (crust and crumb included) and mastication with the molar teeth up to swallowing. The attributes assessors finally agree were appearance (by observing the product slice), flavor and taste. The descriptors for each attributes were appearance (visually liking or disliking), flavor (scale goes from high when typical of bread or bakery products to low, uncharacteristic of bakery products), taste (scale goes from high when typical taste of bread or bakery products to low, uncharacteristic of bakery products). 
Attribute intensity was scored on a scale varying from 1 (disliked extremely) to 9 (like extremely). Two samples were evaluated during one session. Breads were considered acceptable if their means score for overall acceptance were above 5 .

\section{Statistical Analysis}

Data were subjected to multifactor analysis of variance (ANOVA) to study the differences in bread quality induced by the kind of treatment and the chickpea flour level incorporated in the blends. A multiple sample comparison was carried out for analyzing bread parameters and pasting properties of flour individually. Fisher's least significant difference (LSD) test was used to describe means with 95\% confidence. StatgraphicsPlus Centurion XVI (Statpoint Technologies, Warrenton, USA) was used as the statistical analysis software.

\section{Results and Discussion}

The composition of raw and treated chickpea seeds is presented in Table 1 . There was a significant $(P<0.05)$ increase in the protein content of the chickpea, this increase was also noted by Camacho et al. [17] during germination of beans, chickpea and pea's seeds. Hsu et al. [18] observed that protein content of legumes generally increase during germination as a result of biochemical changes induced by sprouting, leading to an increase in free amino acids. Conversely, toasting slightly decrease the protein content. Seeds that were subjected to soaking; showed lower carbohydrates content due to the losses of the water soluble compounds. Conversely, germination was the only process that decreased the amount of fat content due to the germination process itself, and differences were not significant with the raw seeds. Germinated and cooked chickpea exhibited lower ash content than raw and toasted ones. This significant $(P<0.05)$ decrease might be caused by leaching and diffusion of water soluble compounds into soaking and cooking water. These results are in agreement with those observed by Alajaji and ElAdawy [19] in chickpeas.

TABLE 1.PROXIMATE COMPOSITION OF PROCESSED CHICKPEA FLOURS (\% AS IS)

\begin{tabular}{|c|c|c|c|c|}
\hline Treatment & Protein (\%) & Carbohydrates* $(\%)$ & Fat (\%) & Ash (\%) \\
\hline Raw & $21.85 \pm 0.18 \mathrm{~b}$ & $66.42 \pm 0.74 \mathrm{a}$ & $6.36 \pm 0.49 \mathrm{ab}$ & $2.92 \pm 0.03 \mathrm{a}$ \\
\hline Germinated & $22.27 \pm 0.14 \mathrm{a}$ & $65.93 \pm 0.20 \mathrm{~b}$ & $6.21 \pm 0.29 \mathrm{~b}$ & $2.66 \pm 0.04 \mathrm{~b}$ \\
\hline Toasted & $21.44 \pm 0.12 \mathrm{c}$ & $66.49 \pm 0.65 \mathrm{a}$ & $6.85 \pm 0.11 \mathrm{a}$ & $3.07 \pm 0.50 \mathrm{a}$ \\
\hline Cooked & $21.88 \pm 0.11 \mathrm{~b}$ & $65.90 \pm 0.37 \mathrm{~b}$ & $6.93 \pm 0.50 \mathrm{a}$ & $2.19 \pm 0.39 \mathrm{c}$ \\
\hline
\end{tabular}

A Means in a column with different letters are significantly different $(P<0.05)$.

${ }^{*}$ Carbohydrate content was calculated by difference.

\section{Pasting Properties of Flour Mixtures}

The pasting properties of wheat and flour blends were determined following a heating-cooling cycle (Figure 1) and parameters recorded from the pasting curves are shown in Table 2. Overall, the presence of chickpea flour lowered the wheat viscosity profile and the effect was intensified when increasing the level of wheat replacement. The effect was readily evident when reaching the maximum viscosity and differences were kept along holding at $95{ }^{\circ} \mathrm{C}$ and cooling. The $20 \%$ composite slurries peaked earlier during heating than the $10 \%$ and control wheat slurry. Considering the type of process, cooked chickpea flour gave the lowest paste viscosities followed by germinated chickpea, and those effects were even more pronounced with $20 \%$ replacement. Presumably, the removal of water soluble compounds plus partial gelatinization of starch during cooking would explain the behavior of wheatcooked chickpea blends. Conversely, pasting profile obtained with germinated flour should be explained by the activation of enzymes during germination, as reported Cornejo and Rosell [20] with germinated rice flour. Toasting was the least severe processing, since wheat blends showed similar plots to wheat flour. Likely toasting inactivated endogenous enzymes present in chickpea having less impact in wheat pasting performance than raw chickpea. 


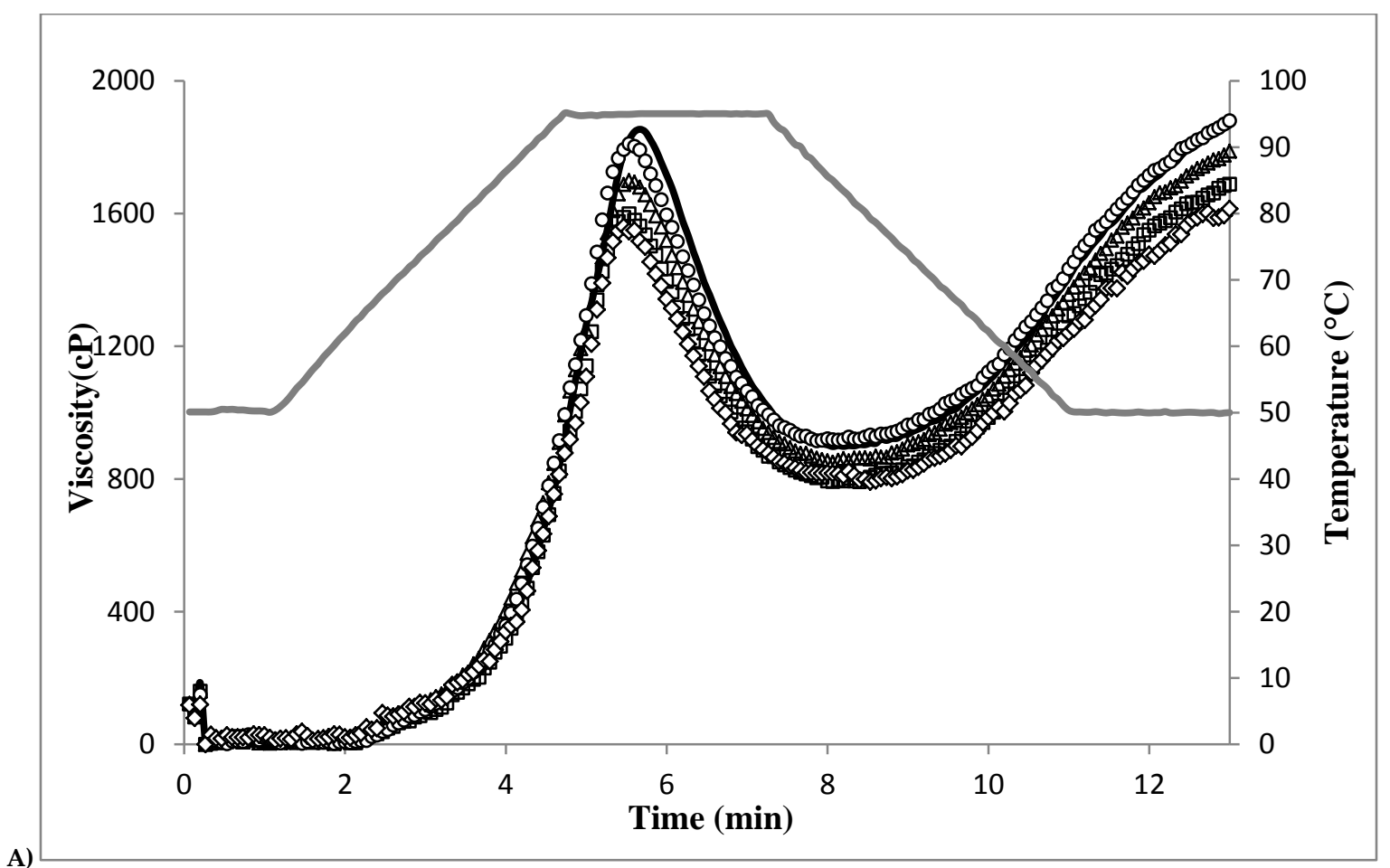

A)

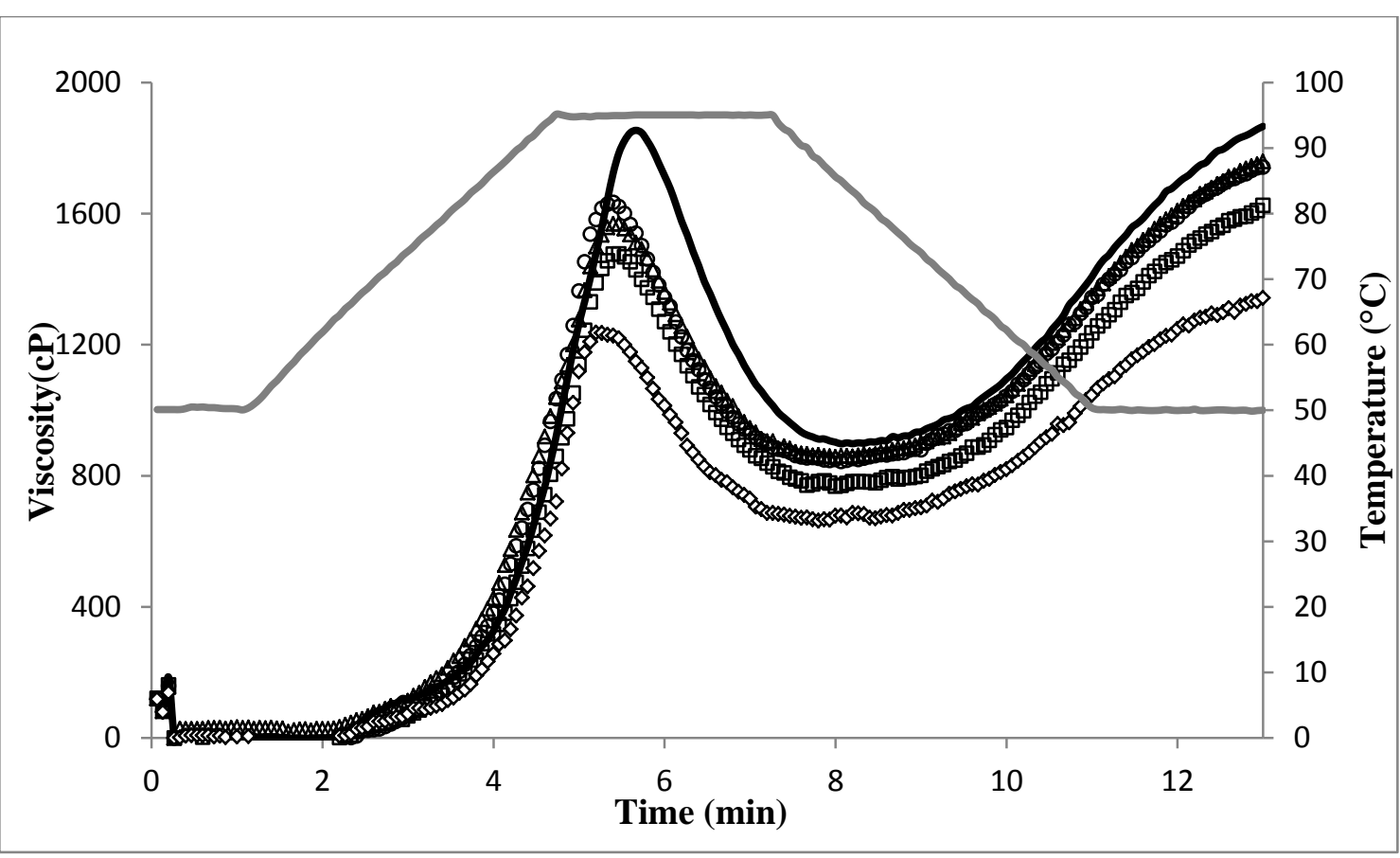

FIGURE 1. RVA PROFILES OF COMPOSITE FLOURS CONTAINING CHICKPEA FLOURS AT 10\% (A) OR 20\% (B) LEVEL OF WHEAT REPLACEMENT .LEGENDS: WHEAT (SOLID BLACK LINE), RAW CHICKPEA $(\Delta)$, GERMINATED CHICKPEA ( $\square$ ), TOASTED CHICKPEA $(\mathbf{O})$, COOKED CHICKPEA $(\diamond)$.

Significant differences were observed in pasting parameters among wheat-chickpea flour blends (Table 2), except for the pasting temperature. Differences were induced by the presence of processed chickpea flour and also by the level of legume flour, as revealed the statistical analysis. The maximum viscosity reached by wheat and composite flours varied from 1240 to $1854 \mathrm{cP}$, obtaining the lowest value at $20 \%$ wheat replacement and particularly in the case of cooked chickpea flour $(\mathrm{C} 20 \%)$ due to legume starch pre-gelatinization during cooking. The breakdown that measures how the swollen granules get disintegrated upon shearing decreased significantly in all composite slurries. The highest decrease (40\%) was observed in C20\% (578 cP), indicating its lowest paste stability. Sandeep et al. [21] pointed out that proteins could provide some protection against the breakdown due to the contribution of 
denatured proteins to support the structure of the matrix and inhibiting the thixotropic nature of starch in flour, but it seems that the protection effect would be dependent on the proteins nature because it was not observed in the chickpea flours. As the paste was cooled down, the viscosity increased due to the aggregation of the amylose molecules. The composite slurries gave slightly lower final viscosities and lower setback except for the $\mathrm{C} 10 \%$ and C20\%, which was significantly lower. The slurries of these blends swelled faster and bound more water; however, less retrogradation occurred leading to less viscous gel after cooking and cooling. Presumably, the lowest setback obtained with $\mathrm{C} 10 \%$ and $\mathrm{C} 20 \%$ might be ascribed to lower amylose content, which leached out during chickpea cooking.

TABLE 2. PASTING PROPERTIES OF COMPOSITE FLOUR CONTAINING CHICKPEA FLOUR AT 10\% OR 20\% LEVEL OF WHEAT REPLACEMENT

\begin{tabular}{|c|c|c|c|c|c|}
\hline Flours & Pasting Temperature $\left({ }^{\circ} \mathbf{C}\right)$ & Peak Viscosity (cP) & Breakdown (cP) & Final Viscosity (cP) & Setback (cP) \\
\hline W & $65 \pm 1$ & $1854 \pm 3 \mathrm{f}$ & $959 \pm 1 \mathrm{~g}$ & $1866 \pm 7 \mathrm{fg}$ \\
\hline R 10 & $58 \pm 10$ & $1699 \pm 8 \mathrm{e}$ & $852 \pm 4 \mathrm{e}$ & $1788 \pm 4 \mathrm{ef}$ \\
G 10 & $67 \pm 3$ & $1599 \pm 113 \mathrm{~cd}$ & $811 \pm 43 \mathrm{~d}$ & $1689 \pm 120 \mathrm{~cd}$ \\
T 10 & $59 \pm 10$ & $1812 \pm 2 \mathrm{f}$ & $899 \pm 11 \mathrm{f}$ & $1880 \pm 6 \mathrm{~g}$ \\
C 10 & $59 \pm 9$ & $1538 \pm 32 \mathrm{bc}$ & $771 \pm 2 \mathrm{c}$ & $1590 \pm 34 \mathrm{~b}$ \\
\hline R 20 & $65 \pm 12$ & $1570 \pm 42 \mathrm{~cd}$ & $714 \pm 2 \mathrm{~b}$ & $1759 \pm 56 \mathrm{de}$ \\
G 20 & $66 \pm 17$ & $1480 \pm 13 \mathrm{~b}$ & $713 \pm 1 \mathrm{~b}$ & $1625 \pm 20 \mathrm{bc}$ \\
T 20 & $72 \pm 6$ & $1634 \pm 18 \mathrm{de}$ & $791 \pm 6 \mathrm{~cd}$ & $1742 \pm 41 \mathrm{de}$ \\
C 20 & $57 \pm 9$ & $1240 \pm 17 \mathrm{a}$ & $578 \pm 37 \mathrm{a}$ & $859 \pm 5 \mathrm{~d}$ \\
\hline P-value & & & & $1343 \pm 16 \mathrm{a}$ \\
Factor 1 & 0.580 & 0.001 & 0.001 & $680 \pm 4 \mathrm{da}$ \\
Factor 2 & 0.400 & 0.000 & 0.000 & 0.001 \\
\hline
\end{tabular}

Mean \pm standard deviation values followed by different letters within a column denote significantly different levels $(P<0.05)(\mathrm{n}=3)$. Factor 1 : Flour; Factor 2: Level of substitution.

W: Wheat, R: raw chickpea, G: germinated chickpea, T: toasted chickpea, C: cooked chickpea.

\section{Bread Characterization}

Photographs of breads made with different processed chickpea flours are shown in Figure 2. Cross-section of bread slices displayed open and aerated crumb structure, which had even bigger gas cells than the wheat bread.

Results on the physicochemical characteristics (specific volume, moisture and color parameters) of composite bread samples containing 10 and 20\% chickpea flours (raw and processed) are shown in Table 3 . The substitution of the bread by chickpea flour at 10 and $20 \%$ did not significantly $(P<0.05)$ affect the specific volume, with the exception of $\mathrm{C} 20 \%$ that showed a significantly reduced specific volume (Figure 2). An increase in the specific volume was envisaged with $10 \%$ germinated chickpea $(\mathrm{G} 10 \%)(3.06 \mathrm{~mL} / \mathrm{g})$, likely due to the enhancement in hydrolytic enzymatic activity and soluble materials, as has been reported for rice germinated flour [20]. Composite breads could be obtained with $20 \%$ wheat replacement without affecting specific volume and germinated and toasted chickpea flour led higher specific volume, although differences were not significant. Similar trends were reported by Shin et al. [14] when comparing bread made with germinated and cooked soy flour with bread made by untreated soy flour. A decrease in specific volume is usually the effect observed when wheat flour is replaced with legume based ingredients [9, 22]. Gularte et al. [23] found that the incorporation of 50\% legume flour (pea, lentil and bean) increased the specific volume of wheat cakes, whereas chickpea did not significantly affect it. Likely, the adjustment of dough hydration during breadmaking minimized the effect of wheat replacement by chickpea flour.

The flour type and the level of substitution affected significantly $(P<0.05)$ the moisture content of bread, which was higher in the presence of cooked chickpea flour (Table 3). This was attributed to the higher amount of water required for breadmaking when wheat flour was substituted with cooked chickpea flour. 


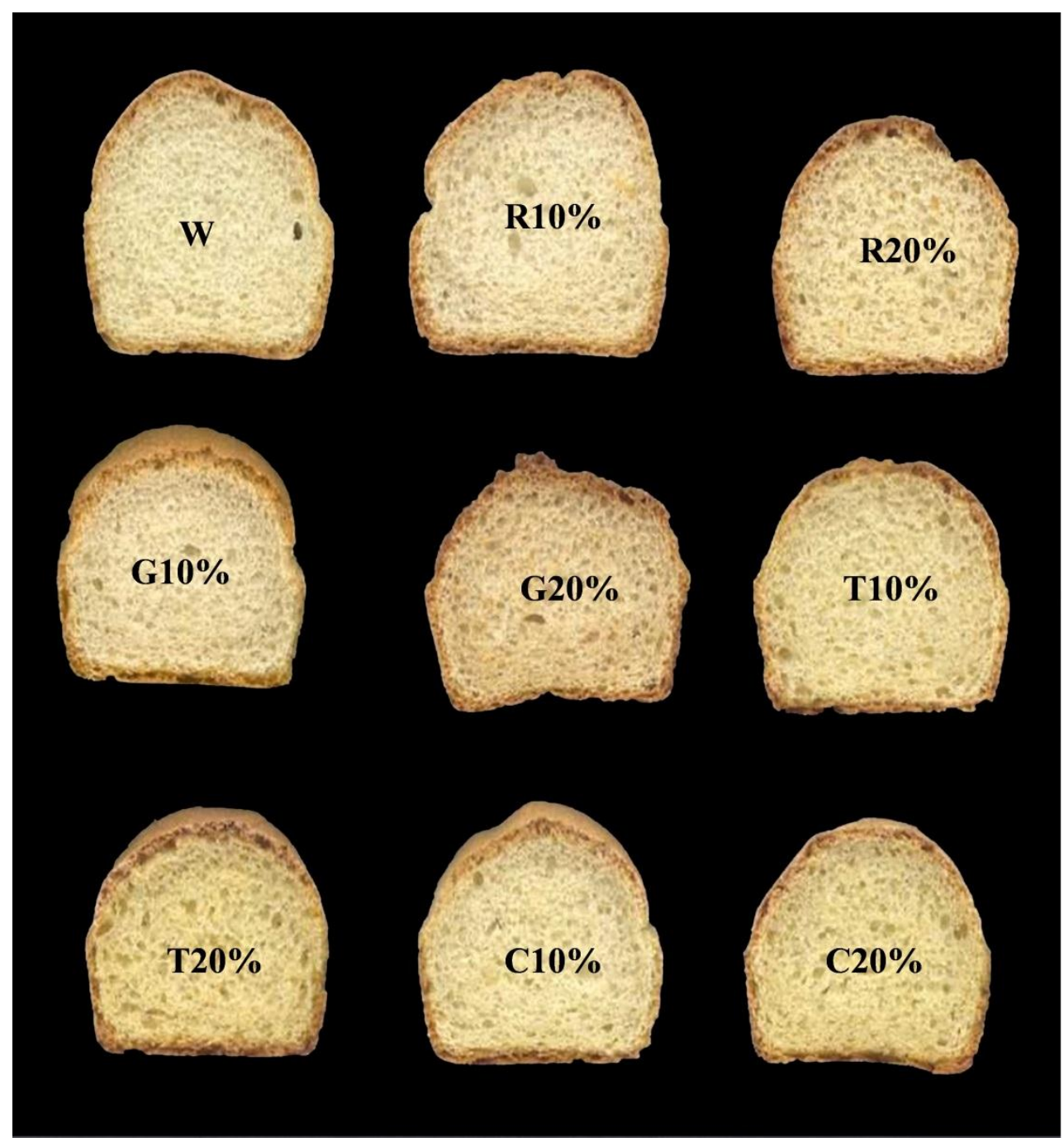

FIGURE 2. PHOTOGRAPH OF BREADS OBTAINED AFTER SUBSTITUTION OF WHEAT FLOUR BY RAW AND PROCESSED CHICKPEA FLOUR AT 10 AND 20\%. LETTERS ARE REFERRED TO THE TYPE OF FLOUR AND PERCENTAGE TO THE AMOUNT OF CHICKPEA FLOUR ADDED. W: WHEAT; R: RAW CHICKPEA; G: GERMINATED CHICKPEA; T: TOASTED CHICKPEA; C: COOKED CHICKPEA.

Color in baked goods could come from different sources: intrinsic color imparted by individual ingredients, developed color resulting from the interaction of ingredients, like Maillard or caramelization reactions, besides processing changes associated to chemical or enzymatic reactions [23]. The substitution of wheat flour with raw and processed chickpea flour affect the color properties of composite breads, inducing a decrease in the whiteness in the composite breads especially for the T20\%, which showed the most dark crumb. This might be due to the chemical browning reactions during toasting [24]. It has been reported that the addition of legume flours to baked products led to darker crumbs [23] in some legume based products. The hue red $\left(a^{*}\right)$ increased significantly $(P<0.05)$ among the composite breads except for the $\mathrm{C} 10 \%$ and $\mathrm{T} 10 \%$. The hue yellow $\left(b^{*}\right)$ significantly $(P<0.05)$ increased when $20 \%$ chickpea flours were present and that effect was also observed with $10 \%$ wheat replacement with toasted and cooked chickpea flour. Similar results have been reported when partial substitution of wheat flour was carried out with different levels (up to 30\%) of raw chickpea flour [25]. The color of crust and crumb got progressively darker as the level of chickpea flour substitution increased. The saturation $\left(C^{*}\right)$ was not affected when the wheat flour was substituted with $10 \%$ of raw and germinated chickpea flour. Conversely, it increased significantly $(P<0.05)$ when this replacement was with thermally treated chickpea flour (toasted and cooked). All the breads made with $20 \%$ substitution increased significantly $(P<0.05)$ the chroma comparing to wheat bread. Regarding the hue angle $h^{\circ}$, it was significantly increased in G10\%, R20\% and G20\% and no effect was detected with thermally treated chickpea flours (toasted and cooked). In opposition, Shin et al. [14] found that heat treated soy flours (steamed and toasted) decreased the $h^{\circ}$ value compared to those non heated soy flours (raw and 
germinated).

The textural properties of composite breads were significantly dependent on the type of flour and level of substitution (Table 4). All the texture parameters tested were statistically $(P<0.05)$ affected by the level of substitution, resulting in an increase of hardness and chewiness when increasing chickpea level and a decrease in springiness and resilience, implying that it will take more time for the structure of the crumb to recover after compression [26]. These results are in concordance with those found by Gomez et al. [9], where resilience decreased though chewiness augmented when increasing chickpea flour percentage in wheat- chickpea cake. Composite breads at $20 \%$ level of substitution had higher hardness and chewiness and less springiness, but the extent of the effect was dependent on the type of chickpea flour. Cooked and germinated chickpea flour at $20 \%$ level gave softer crumbs with lower chewiness and thus they showed easy chewing.

TABLE 3. EFFECT OF ADDING CHICKPEA FLOUR (10\% OR 20\%) IN WHEAT BREAD ON PHYSICAL CHARACTERISTICS OF BREAD

\begin{tabular}{|c|c|c|c|c|c|c|c|}
\hline \multirow{2}{*}{$\begin{array}{c}\text { Bread } \\
\mathrm{s} \\
\end{array}$} & \multirow{2}{*}{\begin{tabular}{|c}
$\begin{array}{c}\text { Specific Volume } \\
(\mathrm{ml} / \mathrm{g})\end{array}$ \\
\end{tabular}} & \multirow{2}{*}{$\begin{array}{c}\text { Moisture } \\
(\%)\end{array}$} & \multicolumn{5}{|c|}{ Color } \\
\hline & & & $L^{*}$ & $a^{*}$ & $b^{*}$ & $C^{*}$ & $h^{\circ}$ \\
\hline Wheat & $2.89 \pm 0.14 \mathrm{bcd}$ & $29.51 \pm 0.29 \mathrm{a}$ & $69.08 \pm 1.74 \mathrm{~d}$ & $-1.22 \pm 0.38$ a & $17.70 \pm 1.80 \mathrm{a}$ & $17.75 \pm 1.78 \mathrm{a}$ & $-1.33 \pm 0.72 \mathrm{ab}$ \\
\hline R 10 & $2.92 \pm 0.08 \mathrm{bcd}$ & $29.13 \pm 0.33 \mathrm{a}$ & $66.40 \pm 1.72 \mathrm{bc}$ & $-0.19 \pm 0.39 \mathrm{~d}$ & $17.08 \pm 1.44 \mathrm{a}$ & $17.08 \pm 1.44 \mathrm{a}$ & $-0.86 \pm 1.33 b c$ \\
\hline G 10 & $3.06 \pm 0.11 \mathrm{~d}$ & $29.46 \pm 0.58 \mathrm{a}$ & $66.94 \pm 1.47 \mathrm{~cd}$ & $0.03 \pm 0.31 \mathrm{~d}$ & $17.96 \pm 0.93 \mathrm{a}$ & $18.01 \pm 0.94 \mathrm{a}$ & $-0.09 \pm 1.60 \mathrm{~d}$ \\
\hline T 10 & $2.99 \pm 0.12 \mathrm{~cd}$ & $29.94 \pm 0.52 \mathrm{ab}$ & $66.49 \pm 1.63 \mathrm{bc}$ & $-1.14 \pm 0.31 \mathrm{ab}$ & $21.52 \pm 1.38 \mathrm{bc}$ & $21.55 \pm 1.37 \mathrm{~b}$ & $-1.52 \pm 0.02 \mathrm{a}$ \\
\hline C 10 & $2.84 \pm 0.16 \mathrm{bc}$ & $31.13 \pm 1.16 \mathrm{bc}$ & $67.54 \pm 1.18 \mathrm{~d}$ & $-1.45 \pm 0.27 \mathrm{a}$ & $21.00 \pm 0.76 \mathrm{~b}$ & $21.05 \pm 0.75 b$ & $-1.50 \pm 0.01 \mathrm{a}$ \\
\hline R 20 & $2.78 \pm 0.27 b$ & $29.40 \pm 0.54 a$ & $66.66 \pm 1.34 \mathrm{bcd}$ & $-0.12 \pm 0.50 \mathrm{~d}$ & $21.95 \pm 1.38 \mathrm{c}$ & $21.96 \pm 1.39 \mathrm{~b}$ & $-0.52 \pm 1.51 \mathrm{~cd}$ \\
\hline G 20 & $2.87 \pm 0.13 \mathrm{bc}$ & $30.49 \pm 0.89 \mathrm{~b}$ & $65.64 \pm 1.23 b$ & $0.88 \pm 0.31 \mathrm{e}$ & $21.52 \pm 0.81 \mathrm{bc}$ & $21.31 \pm 1.28 \mathrm{~b}$ & $1.37 \pm 0.71 \mathrm{e}$ \\
\hline Т 20 & $2.83 \pm 0.22 \mathrm{bc}$ & $30.93 \pm 0.66 \mathrm{~b}$ & $63.66 \pm 1.36 \mathrm{a}$ & $-0.52 \pm 0.42 \mathrm{c}$ & $26.18 \pm 1.33 \mathrm{e}$ & $26.19 \pm 1.32 \mathrm{~d}$ & $-1.20 \pm 1.00 \mathrm{ab}$ \\
\hline C 20 & $2.37 \pm 0.10 \mathrm{a}$ & $32.10 \pm 1.34 \mathrm{c}$ & $66.17 \pm 1.95 b c$ & $-0.91 \pm 1.09 \mathrm{~b}$ & $24.84 \pm 1.34 \mathrm{~d}$ & $24.88 \pm 1.34 \mathrm{c}$ & $-1.18 \pm 0.98 \mathrm{ab}$ \\
\hline $\begin{array}{c}P- \\
\text { value }\end{array}$ & & & & & & & \\
\hline $\begin{array}{c}\text { Factor } \\
-1\end{array}$ & 0.000 & 0.000 & 0.000 & 0.000 & 0.000 & 0.000 & 0.000 \\
\hline $\begin{array}{c}\text { Factor } \\
-2\end{array}$ & 0.000 & 0.000 & 0.000 & 0.000 & 0.000 & 0.000 & 0.000 \\
\hline
\end{tabular}

Mean \pm standard deviation values followed by different letters within a column denote significantly different levels $(P<0.05)(n=4)$. Factor 1 : type of flour; Factor 2: Level of substitution.

R: raw chickpea, G: germinated chickpea, T: toasted chickpea, C: cooked chickpea.

TABLE 4. EFFECT OF PROCESSED CHICKPEA (10\% OR 20\%) ON WHEAT BREAD TEXTURE AND SENSORY PARAMETERS

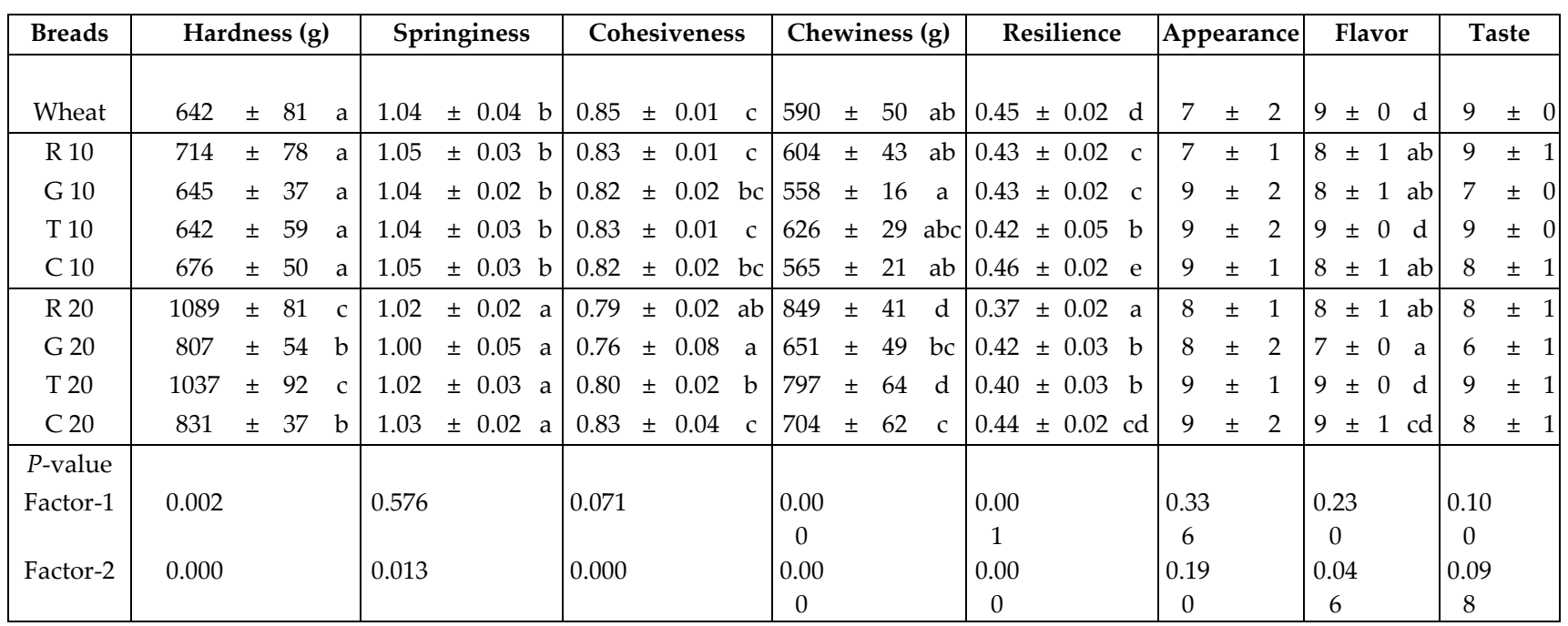

Mean \pm standard deviation values followed by different letters within a column denote significantly different levels $(P<0.05)(n=4)$. Factor 1 : type of flour; Factor 2: Level of substitution. R: raw chickpea, G: germinated chickpea, T: toasted chickpea, C: cooked chickpea, W: wheat.

\section{Chemical Characterization of Bread}

The wheat replacement by chickpea flour significantly changed the chemical composition of breads, and also the 
type of flour significantly affected the composition pattern (Table 5). Ash content gradually increased in all composite breads as compared to the control except for the $\mathrm{C} 10 \%$, which agrees with the lower ash content measured in the cooked flour. Similar results were obtained by Saleh et al. [10] and Ndife et al. [13] in breads substituted by soya beans and chickpea.

TABLE 5. EFFECT OF ADDING CHICKPEA FLOUR (10\% OR 20\%) ON WHEAT BREAD PROXIMATE COMPOSITION (EXPRESSED AS PERCENTAGE AS IS BASIS)

\begin{tabular}{|c|c|c|c|c|c|c|c|c|c|c|c|c|c|c|c|c|}
\hline \multirow{2}{*}{$\begin{array}{l}\text { Breads } \\
\text { Wheat }\end{array}$} & \multicolumn{4}{|c|}{ Protein $(\%)$} & \multicolumn{4}{|c|}{ Carbohydrate (\%) } & \multicolumn{4}{|c|}{ Fat (\%) } & \multicolumn{4}{|c|}{ Ash (\%) } \\
\hline & 9.26 & \pm & 0.00 & $\mathrm{a}$ & 59.51 & \pm & 0.03 & $\mathrm{~g}$ & 0.16 & \pm & 0.01 & $\mathrm{a}$ & 1.64 & \pm & 0.03 & $\mathrm{a}$ \\
\hline R 10 & 9.97 & \pm & 0.02 & $\mathrm{~d}$ & 57.78 & \pm & 0.03 & de & 0.31 & \pm & 0.02 & c & 1.78 & \pm & 0.01 & $\mathrm{bc}$ \\
\hline G 10 & 10.06 & \pm & 0.01 & $\mathrm{~d}$ & 58.90 & \pm & 0.03 & $\mathrm{f}$ & 0.31 & \pm & 0.01 & c & 1.80 & \pm & 0.01 & c \\
\hline Т 10 & 9.86 & \pm & 0.14 & c & 57.72 & \pm & 0.15 & d & 0.29 & \pm & 0.02 & $\mathrm{~b}$ & 1.73 & \pm & 0.01 & $\mathrm{~b}$ \\
\hline C 10 & 9.56 & \pm & 0.04 & $\mathrm{~b}$ & 55.37 & \pm & 0.01 & $\mathrm{~b}$ & 0.34 & \pm & 0.00 & $\mathrm{~d}$ & 1.63 & \pm & 0.05 & $\mathrm{a}$ \\
\hline R 20 & 10.75 & \pm & 0.02 & $\mathrm{~h}$ & 57.88 & \pm & 0.06 & e & 0.48 & \pm & 0.01 & $\mathrm{f}$ & 1.98 & \pm & 0.05 & $\mathrm{e}$ \\
\hline G 20 & 10.35 & \pm & 0.04 & $\mathrm{f}$ & 55.75 & \pm & 0.04 & c & 0.44 & \pm & 0.02 & e & 1.89 & \pm & 0.01 & $\mathrm{~d}$ \\
\hline Т 20 & 10.63 & \pm & 0.02 & $\mathrm{~g}$ & 55.42 & \pm & 0.01 & $\mathrm{~b}$ & 0.45 & \pm & 0.01 & e & 1.90 & \pm & 0.02 & $\mathrm{~d}$ \\
\hline C 20 & 10.24 & \pm & 0.01 & e & 54.14 & \pm & 0.03 & $\mathrm{a}$ & 0.57 & \pm & 0.00 & $\mathrm{~g}$ & 1.73 & \pm & 0.02 & $\mathrm{~b}$ \\
\hline$P$-value & & & & & & & & & & & & & & & & \\
\hline Factor-1 & 0.008 & & & & 0.003 & & & & 0.004 & & & & 0.002 & & & \\
\hline Factor-2 & 0.000 & & & & 0.000 & & & & 0.000 & & & & 0.000 & & & \\
\hline
\end{tabular}

Mean \pm standard deviation values followed by different letters within a column denote significantly different levels $(P<0.05)(n=4)$. Factor 1 : type of flour; Factor 2: Level of substitution.

R: raw chickpea, G: germinated chickpea, T: toasted chickpea, C: cooked chickpea, W: wheat.

${ }^{*}$ Carbohydrate content was calculated by difference.

Fat content was statistically $(P<0.05)$ affected by substituting wheat flour by raw and treated chickpea flour, increasing with the level of replacement. Cooked flour was the one that majorly increased the fat content. The high fat content in chickpea flour ( 6-7\%) must have contributed to increasing fat content in composite bread comparing with control bread made with 100\% wheat flour. As expected, the protein content in breads augmented with the level of wheat replacement by chickpea flour. The highest increase in protein content was observed in breads containing germinated chickpea flour. Similar results are found in literature about some legume based products $[10,13]$. Carbohydrate content decreased in all composite breads. These results were expected due to the supplementation of wheat flour with legume flour (chickpea) that contains lower amount of carbohydrate. Results are in agreement with those found by Rababah et al. [27] and Ndife et al. [13].

In general, composite breads gave sensory acceptable breads and met sensory standards receiving approval by judges (Table 4). No significant differences were induced in the appearance, flavor and taste due to the type of chickpea flour or the level of replacement, with exception of the effect of level on the flavor. In terms of appearance the panel considered that $\mathrm{C} 10 \%$ had the best appearance comparing with other composite breads and control wheat bread (W). Concerning flavor, breads containing toasted flour were highly appreciated due to toasting liberated some volatile compounds making the flour smell good.

\section{Conclusion}

Chickpea processing (germination, toasting, and cooking) led to flours with different chemical composition, main effect was the decrease in protein and fat due to germination and the decrease in carbohydrate due to soaking of seeds during germination and cooking. The cooking process induced the greatest effect due to the loss of water soluble compounds. Pasting properties of the wheat-chickpea blends were significantly modified due to wheat flour replacement by 10 and $20 \%$. Cooked flour induced the greatest decrease in viscosity due to starch gelatinization during cooking. Conversely, toasting promoted the least effect due to the inactivation of the chickpea enzymes, and behavior was rather similar to raw seeds flour. Regarding bread quality, wheat replacement by $10 \%$ processed chickpea flour led breads with similar technological and sensory characteristics than wheat bread. The increasing replacement (20\%) resulted in harder breads, especially in the case of raw and toasted flour (1089 $\mathrm{g}$ and $1037 \mathrm{~g}$ vs $714 \mathrm{~g}$ and $642 \mathrm{~g}$ when $10 \%$ replacement, respectively). Overall, germinated chickpea flours were the most 
appropriate flour for wheat replacement pertaining bread specific volume crumb hardness and nutritional composition (higher protein content), but they worsened when $20 \%$ replacement. Conversely, although toasted flour impaired hardness, it gave pleasant flavor that was really appreciated.

\section{ACKNOWLEDGMENT}

The authors acknowledge the financial support of Spanish National Research Council (CSIC) and the GeneralitatValenciana (Spain, Project Prometeo 2012/064). They thank the University of Abderahmane Mira for supporting predoctoral stay of MrsOuazib.

\section{REFERENCES}

[1] FAO. Food Energy-Methods of Analysis and Conversion Factors, Rome: Food and Agriculture Organization of the United Nations, 2003.

[2] Singh K.B. and Ocampo B. "Exploitation of Wild Cicer Species for Yield Improvement in Chickpea."Theoreticaland Applied Genetics 95(1997): 418-423.

[3] Maatougui M.E.La Culture des Légumineuses à Graines. Premier séminaire sur les légumineuses en Algérie. Ain Témouchent,1998.

[4] Ravi R. and Bhattacharya S. "Flow Behaviour of Chickpea (Cicer arietinum L.) Flour Dispersions: Effect of Additives."Journal of Food Engineering 65 (2004): 619-624.

[5] Wood J.A. and Grusak M.A. "Nutritional Value of Chickpea." In: Chickpea Breeding and Management, edited byYadavS.S., Redden B. Chen W. and Sharma B., 143-166. CAB International, Wallingford, UK, 2007.

[6] Attia R. S., Shehata A.M.E., Aman M.E. and Hamza M.A. "Effect of Cooking and Decortication on the Physical-Properties, the Chemical-Composition and the Nutritive Value of Chickpea (Cicer-artietinum)."Food Chemistry50 (1994): 125-131.

[7] Uchendu F. N., Atinmo T. and Oyewole O. "Stability of Vitamin a in Selected Nigerian Bread Made from Commercial Fortified Wheat Flour."InternationalJournal of Advanced Science and Technology 2 (2012): 93-98.

[8] Anjum F.M., Ahmad I., Butt M.S., Sheikh M.A. and Pasha I. "Amino Acid Composition of Spring Wheats and Losses of Lysine During Chapati Baking." Journal of Food Composition and Analysis18 (2005): 523-532.

[9] Gomez M., OlieteB.,RosellC.M., Pando V. and Fernandez E. "Studies on Cake Quality Made of Wheat-Chickpea Flour Blends."LWT-Food Science and Technology41 (2008): 1701-1709.

[10] SalehA. M., Salama A.E., Bedeir S.H. and Abd-Elazim E.I. "Effect of Partial Substitution of Wheat Flour with Either Defatted Soybean or Chickpea Flours at Different Ratios on Rheological and Physical Properties of Dough, and Quality Characteristics of Biscuits." Journal of Applied Sciences Research 8 (2012): 5806-5817.

[11] Singh N., Harinder K., Sekhon K.S. and Kaur B. "Studies on the Improvement of Functional and Baking Properties of Wheat-Chickpea Flour Blends." Journal of Food Processing and Preservation15 (1991): 391-402.

[12] Luz Fernandez M. and Berry J.W. "Rheological Properties of Flour and Sensory Characteristics of Bread Made from Germinated Chickpea." International Journal of Food Science and Technology 24 (1989): 103-110.

[13] Ndife J., Abdulraheem L.O. and Zakari U.M. "Evaluation of the Nutritional and Sensory Quality of Functional Breads Produced from Whole Wheat and Soya Bean Flour Blends." African Journal of Food Science5(2011): 466-472.

[14] Shin D. J., Kim W.and Kim Y."Physicochemical and Sensory Properties of Soy Bread Made with Germinated, Steamed, and Roasted Soy Flour." Food Chemistry141 (2013): 517-523.

[15] Association of Official Analytical Chemists (AOAC), Official Methods of Analysis. AOAC, Washington DC., 1990.

[16] American Association of Cereal Chemists International (AACCI), Approved Methods of Analysis, 11th edition,Method 6102. St. Paul, MN, USA (Approved October 15), 2010.

[17] Camacho L., Sierra C., Campos R., Guzman E. and Marcus D. "Nutritional Changes Caused by the Germination of Legumes Commonly Eaten in Chile." ArchivosLatinoamericanos deNutricion42 (1992):283-90. 
[18] Hsu D.L., Leury H.K., Finney P.L.andMorad M.M. “Effects of Germination on the Nutritive Value and Baking Properties of Dry Peas, Lentils and FabaBeans."Journal of Food Science45 (1980): 87-90.

[19] Alajaji S. A. and El-Adawy T.A. "Nutritional Composition of Chickpea (CicerarietinumL.)as Affected by Microwave Cooking and Other Traditional Cooking Methods." Journal of Food Composition and Analysis19 (2006): 806-812.

[20] CornejoF.andRosell C.M. "Influence of Germination Time of Brown Rice in Relation to Flour and Gluten Free Bread Quality." Journal of Food Science and Technology (2014). doi: 10.1007/s13197-015-1720-8.

[21] Sandeep S., Singh N. and MacRitchie F. "Relationship of Polymeric Proteins with Pasting, Gel Dynamic- and Dough Empirical-Rheology in Different Indian Wheat Varieties." Food Hydrocolloids 25 (2011): 19-24.

[22] Pollard N. J., Stoddard F.L. Popineau, Y., Wrigley C.W.andMacRitchie F. “Lupin Flours as Additives: Dough Mixing, Breadmaking, Emulsifying, and Foaming."Cereal Chemistry79 (2002): 662-669.

[23] Gularte M. A., Gomez M. and Rosell C.M. “Impact of Legume Flours on Quality and In Vitro Digestibility of Starch and Protein from Gluten-Free Cakes."Food Bioprocess Technology5 (2012): 3142-3150.

[24] Whistler R. and BeMillerJ.“Carbohydrate Chemistry for Food Scientists.” Food Australia60 (2008): 146-146.

[25] Mohammed I., Ahmed A.R.andSenge B. "Dough Rheology and Bread Quality of Wheat-Chickpea Flour Blends." Industrial Crops and Products36 (2012): 196-202.

[26] Martínez-Cervera S., Salvador A., Muguerza B., Moulay L. and FiszmanS.“CocoaFibre and its Application as a Fat Replacer in Chocolate Muffins."LWT- Food Science and Technology44 (2011): 729-736.

[27] Rababah T. M., Al-Mahasneh M. A. and Ereifej K.I. “Effect of Chickpea, Broad Bean, or Isolated Soy Protein Additions on the Physicochemical and Sensory Properties of Biscuits." Journal of Food Science 71 (2006): S438-S442. 